\title{
The Evaluation Of \\ "Bahasa Inggris Maritim Dan Perikanan Paket Keahlian: Teknika Kapal Penangkapan Ikan Kelas X"
}

Stellar Nube Mella,

Petra Christian University, Surabaya, Indonesia

m11413072@john.petra.ac.id

\begin{abstract}
The purpose of this present study is to identify the extent to which the ESP textbooks Bahasa Inggris Maritim dan Perikanan Paket Keahlian: Teknika Kapal Penangkapan Ikan Kelas X Semester I (BIMP I) and Bahasa Inggris Maritim dan Perikanan Paket Keahlian: Teknika Kapal Penangkapan Ikan Kelas X Semester II (BIMP II) comply with the criterions of ESP textbooks evaluation checklist proposed by Cunningsworth (1995), namely the $7^{\text {th }}, 8^{\text {th }}, 9^{\text {th }}$, and $11^{\text {th }}$ criterions of the checklist. This study is a qualitative research in which the writer read both ESP textbooks BIMP I and BIMP II and used content analysis to analyze the textbooks. Through the evaluation of both the ESP textbooks BIMP I and BIMP II, the writer discovered that out of the four criterions used, the ESP textbooks partially met the ninth and eleventh criteria which are; the usability of the ESP textbooks for individual study, and the availability of outcomes of learning activities relevant to student's future professions/ occupations. This present study would hopefully make several noteworthy contributions to the quality improvement of both BIMP I and BIMP II textbooks.
\end{abstract}

Keywords: English for Specific Purposes, textbook, textbook evaluation.

Textbook evaluation has an important role in ESP language teaching and learning. The ESP textbooks evaluated for this study that are Bahasa Inggris Maritim dan Perikanan Paket Keahlian: Teknika Kapal Penangkapan Ikan Kelas X Semester I (BIMP I) and Bahasa Inggris Maritim dan Perikanan Paket Keahlian: Teknika Kapal Penangkapan Ikan Kelas X Semester II (BIMP II). To evaluate these two textbooks, the writer used the ESP materials evaluation checklist proposed by Cunningsworth (1995). The writer focused on four criterions as described below.

$7^{\text {th }}$ Criteria/ Does the material consider the relationship between teachers and students? If so, is a collaborative appoach encouraged?

$8^{\text {th }}$ Criteria/ Is the material sufficiently flexible to meet the constrainst often found in ESP work, e.g. by having a modular structure of non-sequential units?

$9^{\text {th }}$ Criteria/ Can the material be used for individual study? If so, are learners given guidance on how to use the material in this way?

$11^{\text {th }}$ Criteria/ Do learning activies have outcomes or products which will help learners to evaluate their performance?

(Cunningsworth, 1995, p. 135)

\section{METHODS}

In this study, the writer used the qualitative approach, in particular, a documentary analysis. The data collection was conducted by the writer in which, the writer read by reading the two ESP textbooks which are Bahasa Inggris Maritim dan Perikanan Paket Keahlian: Teknika Kapal Penangkapan Ikan Kelas X Semester I (BIMP I) and Bahasa Inggris Maritim dan Perikanan Paket Keahlian: Teknika Kapal Penangkapan Ikan Kelas X Semester II (BIMP II), and evaluated the textbooks using the criteria proposed by Cunningsworth (1995). 


\section{FINDINGS AND DISCUSSIONS}

7. The Consideration of the Relationship between Teachers and Students in the ESP Textbooks

Through the evaluation of the ESP textbooks BIMP I and BIMP II, it is found that roles and relationship between students and teachers portrayed in both ESP textbooks do not resemble that of a conventional ESP course where the position of teacher and learners are often more equal and that a cooperative relationship combining knowledge and expertise of the teacher and students are encouraged.

According to Cunningsworth (1995), in language learning, the teacher acts as; a guide, mentor, facilitator, manager of learning, director, and monitor (p. 111). Furthermore, Cunningsworth (1995) mentions that in general, textbooks identify the primary role of the teacher as a guide or facilitator, and a monitor. Thus, the teacher is seen as guiding learners through the learning process with support from the textbook and monitoring student's progress, correcting errors when it is useful in the learning process (Cunningsworth, 1995). Furthermore, as mentioned by Cunningsworth (1995), the learner's role in the language-learning process are; to hypothesize about rules, participate actively in learning activities, relate materials to their own experiences and personal lives and undertake a variety of tasks which involve problem solving of one sort or another (p. 105).

In BIMP I, it is found that the teacher functions mostly as an assessor in which the teacher provides student feedback and correction, and grading the student's performance. This is demonstrated through the student assessment/ evaluation section entitled C.Penilaian found in all units except unit 6 in BIMP I. In C. Penilaian, teachers assess students based on three criterions namely sikap (attitude), pengetahuan (knowledge), and keterampilan (skills). 
C. Penilaian

1. Sikap

Nilai diperoleh dari pengamatan guru terhadap keaktifan siswa selama proses pembelajaran berlangsung

Lembar Penilaian Sikap

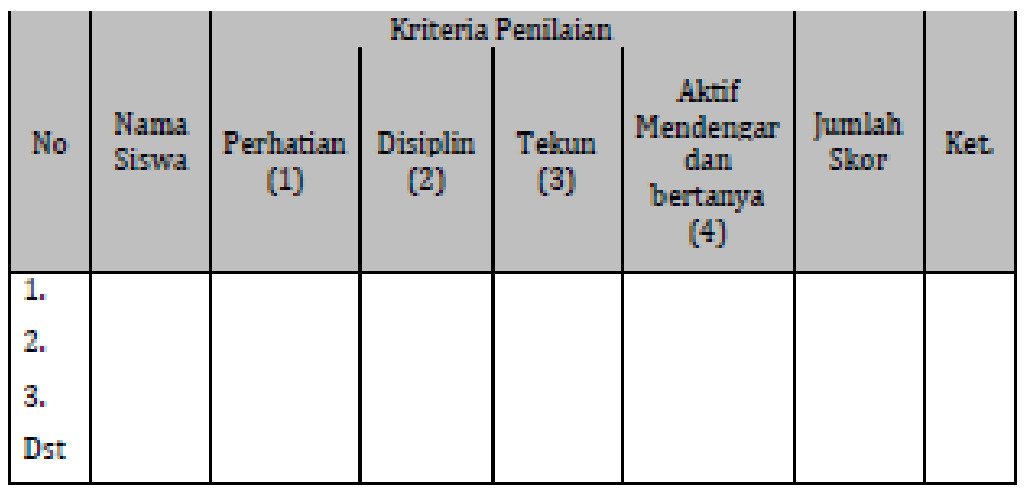

Keterangan Skor :

kolom diisi dengan kriteria sesuai sikap yang ditampilkan oleh peserta didik,

dengan kriteria sebagai berikut :

4 = selalu, apabila selalu melakukan sesuai pernyataan.

3 = sering, apabila sering melakukan sesuai pernyataan dan kadang. kadang tidak melakukan.

2 = kadang-kadang, apabila kadang-kadang melakukan dan sering tidak melakukan.

1 = tidak pernah, apabila tidak pernah melakukan.

Figure 1

Source: BIMP I, 2013, p. 18

Although the roles of the students are not explicitly mentioned, it can be inferred from the textbook BIMP $I$ that the roles of the students include; participating in learning activities, hypothesizing about rules, relating material to their own experiences and personal lives, and undertaking a variety of tasks which involve problem solving of one sort or another.

The student's role as the participant in learning activities and to undertake a variety of tasks can be seen from the instructions of language exercises and practices included in the ESP textbook BIMP I such as the speaking and role play exercises where students are required to participate in the learning activity by practicing the language items and conduct role play as indicated by the instructions.

The role the students to relate material to their own experiences and personal lives can be seen in the second question (point $b$ ) of the student reflection section found in almost all units (except unit 6) in BIMP I. Specifically, in the second question where students are required to state their plans on implementing the knowledge and skill gained through the learning of the unit related to the student's experience. This can be seen in Figure 2 (unit 1, p. 27). 


\section{Refleksi}

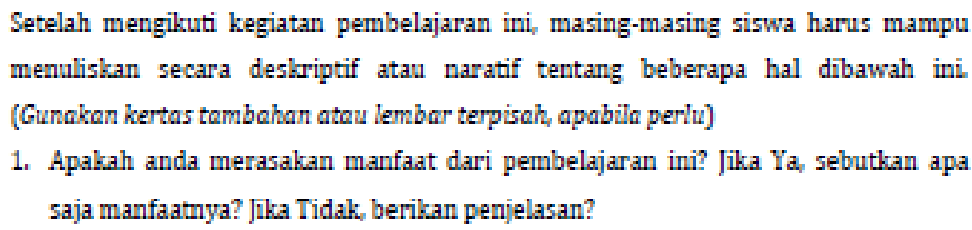

2. Apa rencana implementasi pengetahuan dan keterampilan dari hasil kegiatan pembelajaran ini.

3. Apa saran dan masukkan anda untuk kegiatan pembelajaran selanjutnya.

Figure 2

Source: BIMP II, 2013, p. 27

Another role of the students portrayed in the ESP textbook BIMP I is to hypothesize about rules. This could be identified particularly through the grammar learning sections through which students are expected to have and gain a certain understanding in regards to the uses and forms of grammar items presented.

The role of the teacher in the ESP textbook BIMP II is stated explicitly in the textbook description section on page 2 where it is explicitly mentioned that the ESP textbook is intended to be used in class with the teacher as the facilitator. As a facilitator, the roles that teachers have in class are; controlling, organizing, assessing, prompting, participating, acting as recourse, tutoring, and observing (Harmer, 1991).

However, through the evaluation of the ESP textbook BIMP II, it is found that the teacher's roles only include assessing student performance, and as a resource providing language models for students.

Teacher as an assessor includes providing student feedback and correction, and grading the student's performance in class. The role of the teacher as an assessor of learning could be seen in the student assessment/ evaluation section (C. Penilaian) which is also found in each unit (Kegiatan Pembelajaran) in the ESP textbook BIMP II. 
In the ESP textbook BIMP II, the role of the teacher as a resource involves the teacher acting as a source of language models. This can be identified particularly through the pronunciation/spelling exercises the teacher is tasked at modeling accurate and correct pronunciation which students are required to follow.

Similar to the roles of the students in BIMP I, the roles of the students as inferred from the ESP textbook BIMP II are; relate materials to their own experiences and personal lives through the student reflection sections, and undertake a variety of tasks and to participate in learning activities.

The student's role which involves participating in learning activities and undertaking various tasks could be seen in the unit learning objectives and in the student assessment and evaluation sections.

Thus, as inferred in the ESP textbooks BIMP I and BIMP II, the teacher functions as an assessor of student's performance and source of language models, whereas the students are expected to participate in the learning activities and tasks, and to hypothesize about rules and relate the materials to their own personal experience.

\section{The flexibility of the ESP materials in meeting constraints often found in ESP}

The eighth feature ESP textbooks ought to have discussed by Cunningsworth (1995) focuses on the textbook design. Students of ESP are often occupied by their professions, causing sporadic attendance in ESP courses or classes (Cunningsworth, 1995). Therefore, ESP materials are designed to compensate this by having a modular structure of non-sequenced units (Cunningsworth, 1995).

However, the ESP textbooks BIMP I and BIMP II are intended for students currently enrolling at the vocational high school level, in particular, the first grade of $S M K$. Thus, the target learners of the ESP textbooks are not yet professionals working in a particular profession. This might be the reason why the material of the ESP textbooks BIMP I and BIMP II were designed in a fixed and sequenced approach and not with a modular structure.

The sequenced approach is demonstrated through the presentation of the content of the ESP textbooks in which the material presented progresses in terms of difficulty and complexity. An example of the progression and sequence of the materials presented in the ESP textbooks BIMP I and BIMP II can be seen through the progression of grammar contents covered in the ESP textbook BIMP I in which, the grammar items covered in each unit increases in terms of difficulty as the units progress. The first unit of BIMP I covers Forms of to be (linking verbs). The third and fifth units of BIMP I cover the tenses which are simple present and present continuous, and simple past and past continuous sentences.

In terms of grammar, although the ESP textbooks do not mention the underlying principle of sequencing, it could be deduced that the progression is based on the structure of a sentence. First the pronouns (subject) and progresses to verbs, and later the nouns (objects are then introduced). Then the tense of the sentence is introduced by first introducing the simple present tense and the present continuous tense followed by the past and past continuous tenses.

\section{The Usability of the ESP Textbooks for Individual Study}

The $9^{\text {th }}$ criterion for evaluating ESP materials is the usability of the textbook for individual study. Materials that could be used for individual study often include learning techniques that can be used by the students to enhance and simplify their learning (Cunningsworth, 1995). For his ninth suggested criteria, Cunningsworth (1995) mentions "sections for study skills focus mainly on three different aspects which are; inviting learners to reflect on their learning and the most effective way of learning them; provide advice for learners on how to improve their study skills; teaching students how to use grammar books and dictionaries for reference" (p. 107).

Through the evaluation of the ESP textbooks BIMP I and BIMP II, it is discovered that, in terms of study skills sections, both ESP textbooks only include sections that invite learners to reflect on their learning. This could be found particularly in the Refleksi (or reflection) sections available at the middle of each unit of both ESP textbooks. The Refleksi (or reflection) section is intended to invite the learners to reflect on their learning. However, this section does not include questions inviting students to reflect on the ways of learning that are most effective for them. The reflection sections only include 
questions asking the students to reflect on the merit of learning the content in the chapter, the implementation of knowledge and skill gained from learning the contents in the chapter and suggestions for the next chapter (Kegiatan Pembelajaran).

In terms of offering advice to learners on ways of developing their study skills, both ESP textbooks do not contain sections that are intended for these purposes. Both ESP textbooks do not have sections that are intended to provide information on reference skills for using dictionaries and grammar books.

In addition to study skill sections, textbooks that are suitable for individual study also include workbook, additional reading material, self-study cassette, and key to exercises (Cunningsworth, 1995). These items provide learners with guidance on how to use the textbook and enable students to monitor their own learning. However, workbook, additional reading material, self-study cassette and key to exercises are not available in both the ESP textbooks BIMP I and BIMP II.

\title{
11. Availability of Outcomes or Products from the Learning Activities that Helps Students to Evaluate Their Performance in the Professional/ Occupational Setting
}

As mentioned by Cunningsworth (1995) for his eleventh item of his checklist, the outcomes or products which will help learners to evaluate their performance could be found in task based and skill based activities that mirror real communicative situations students will encounter in their professional/ occupational situation.

From the analysis of the learning activities in the ESP textbooks BIMP I and BIMP II, there are several expected outcomes of the learning activities in BIMP I and BIMP II believed by the writer to be relevant to the student's professional/ occupational situation. These abilities are; the ability to write and read specific texts namely navigational warnings, ship's activity log, and shipping instructions; to provide accurate responses to certain communicative situations in maritime communication, to perform the roles in the activity of a ship leaving port, and to use English in a conversation.

The present analysis shows that the outcomes of the learning activities in the ESP textbook BIMP I include the ability to perform the roles in the activity of a ship leaving port, and the ability to use English language functions in a conversation. The ability to perform the roles in the activity of a ship leaving port is achieved through the role play activity in unit 5 on page 103.

\begin{abstract}
Selanjutnya, bersama-sama praktikkan pengucapan kalimat instruksi yang
sudah dipelajari sebelumnya. Masing-masing harus memiliki kesempatan

untuk melakukannya. Secara berkelompok tentukan peran masing-masing anggota ketika melakukan aktifitas perkapalan/pelayaran saat meninggalkan pelabuhan.
\end{abstract}

Figure 3

Source: BIMP I, 2013, p. 103

In the activity presented in Figure 3, students are instructed to practice or enact role play based on the activity of a ship unberthing or leaving the port. The ability to use English language functions in conversations are acquired through dialogue activities in which the students are required to form groups and conduct dialogues. The expected outcome of these speaking activities is the ability to use English in conversations/ dialogues.

From the analysis of the learning activities in the ESP textbook BIMP II, the outcomes of the learning activities include; the ability to write and read specific texts namely navigational warnings, ship's activity log, and shipping instructions, and to provide accurate responses to certain communicative situations in maritime communication. The ability to write and read specific texts could found on pages 11-12 in unit 1(ship's activity log comprehension), pages 125-128 and 133-134 in unit 5 (navigational notices and warnings comprehension), and page 153 in unit 6 (shipping instructions). 


\section{Tes Formatif}

Study the navigational warning and the text (on the following page) which puts the navigational warning into full sentences.

\section{NAVIGATIONAL. WARNING}

\section{UTC SEP}

BALTIC SEA NAV WARN 008

KATTEGAT. BALTIC SEA. THE SOUND, GULF OF FINLAND

V. LONG TOW (650 M) DEPART GRENEN SWEDEN APPROX 042000 UTC SEP TO

PASS THROUGH DROGDEN

TOWBOAT 'EUROSUND' CALLSIGN OWFB2

WIDE BERTH REQUESTED

Figure 4

Source: BIMP II, 2013, p. 133

In these exercises, students are required to either read the specific texts, or re-write the abbreviated texts into full sentences.

The other outcome discovered in the learning activities in BIMP II is the ability to provide accurate responses to certain communicative situations in maritime communication. This outcome is achieved through the learning activity in exercise 3 found on page 131 of unit 5 .

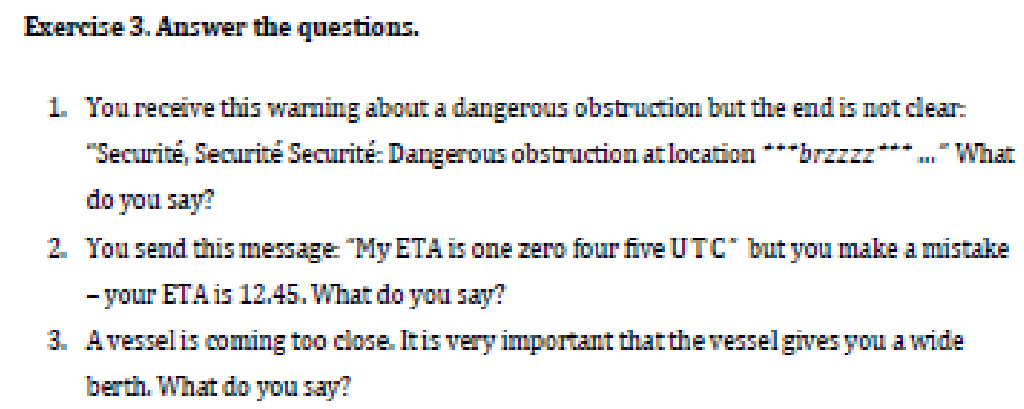

Figure 5

Source: BIMP II, 2013, p. 131

. In the learning activity presented above in Figure 5, students are required to provide the correct response to the communicative situations described in the exercise. Through the exercise, students are expected to have ability to provide accurate responses to certain communicative situations in maritime communication; a situation that these students would likely encounter in their future working field.

\section{CONCLUSION AND SUGGESTIONS}

This paper has identified the extent to which the ESP textbooks BIMP I and BIMP II met the four criterions of the ESP materials evaluation checklist proposed by Cunningsworth (1995). It was found that the ESP textbooks BIMP I and BIMP II only met the $11^{\text {th }}$ criterion and partially met the $9^{\text {th }}$ criterion while failing to comply with the $7^{\text {th }}$ and $8^{\text {th }}$ criterions. Through this present study, it is hoped that several noteworthy contributions could be made to the improvement of the quality of both BIMP I and BIMP II textbooks. 


\section{REFERENCES}

Cunningsworth, A. (1995). Choosing your coursebook. London: Heinemann.

DITPSMK. (2013).Bahasa Inggris maritim dan perikanan: Paket keahlian teknika kapal penangkapan ikan kelas $X$ semester I. Jakarta: Direktorat Pembinaan SMK.

DITPSMK. (2013).Bahasa Inggris maritim dan perikanan: Paket keahlian teknika kapal penangkapan ikan kelas X semester II. Jakarta: Direktorat Pembinaan SMK.

Harmer, J. (1991).The practice of English language teaching. New York: Longman. 